\section{Lav reproduksjonsevne i okkupert palestinsk territorium}

Palestinere i tradisjonelle muslimske landsbyer på Vestbredden hadde

lavere fekunditet enn vestlige befolkningsgrupper. Dette kan skyldes fravær av vestlige sosiokulturelle vaner, som sex før ekteskapet.

I en prospektiv studie ble 205 nygifte par fra to landsbyer i Hebron-distriktet fulgt (1). Ingen av dem hadde hatt sex før ekteskapet. Samtlige par ønsket barn så fort som mulig. De ble fulgt månedlig inntil graviditet ble bekreftet med graviditetstest eller i maksimum 12 måneder ( $100 \%$ deltakelse). $16 \%$ av kvinnene ble gravide i første syklus og $70 \%$ innen sjette. $13 \%$ var ikke blitt gravide innen ett år (subfekunde par).

Gjennomsnittlig fekunditet (evne til reproduksjon), målt som tid til svangerskap, var 0,17 . Uventet var det en initial økning i syklusspesifikk fekunditet fra 0,16 (syklus 1) til 0,25 (syklus 5) hos ektepar der kvinnen var tenåring. Økningen kan ha både kulturelle og biologiske forklaringer og har ikke vært vist i vestlige befolkningsgrupper.
Det er vanskelig å stole på funn fra tilsvarende studier gjort $\mathrm{i}$ Vesten pga. våre innfløkte samlivsformer. Studier gjort i lavinntektsland som sosiokulturelt er svært forskjellige fra de vestlige kan innebære viktige metodiske fortrinn. Studien utgjør en del av et omfattende samarbeid innen forskning og høyere utdanning mellom Avdeling for allmenn- og samfunnsmedisin, Universitetet i Oslo, og palestinske institusjoner (2).

\section{Espen Bjertness \\ espen.bjertness@medisin.uio.no \\ Petter Kristensen \\ Avdeling for allmenn- og samfunnsmedisin Universitetet i Oslo \\ Litteratur \\ 1. Issa Y, Sallmén M, Nijem $K$ et al. Fecundability among newly married couples in agricultural villages in Palestine: a prospective study. Hum Reprod 2010; 25: 2132-8. \\ 2. Bjertness E, Nijem K, Husseini A et al. 15 years of cooperation in research and higher education between the Faculty of Medicine, University of Oslo, and Palestinian institutions. Abstrakt og webappendiks. www.thelancet.com/health-in-the- occupied-palestinian-territory-2010 (23.7.2010)}

\section{VERDENS HELSE}

\section{Tiltak mot barnesexturisme}

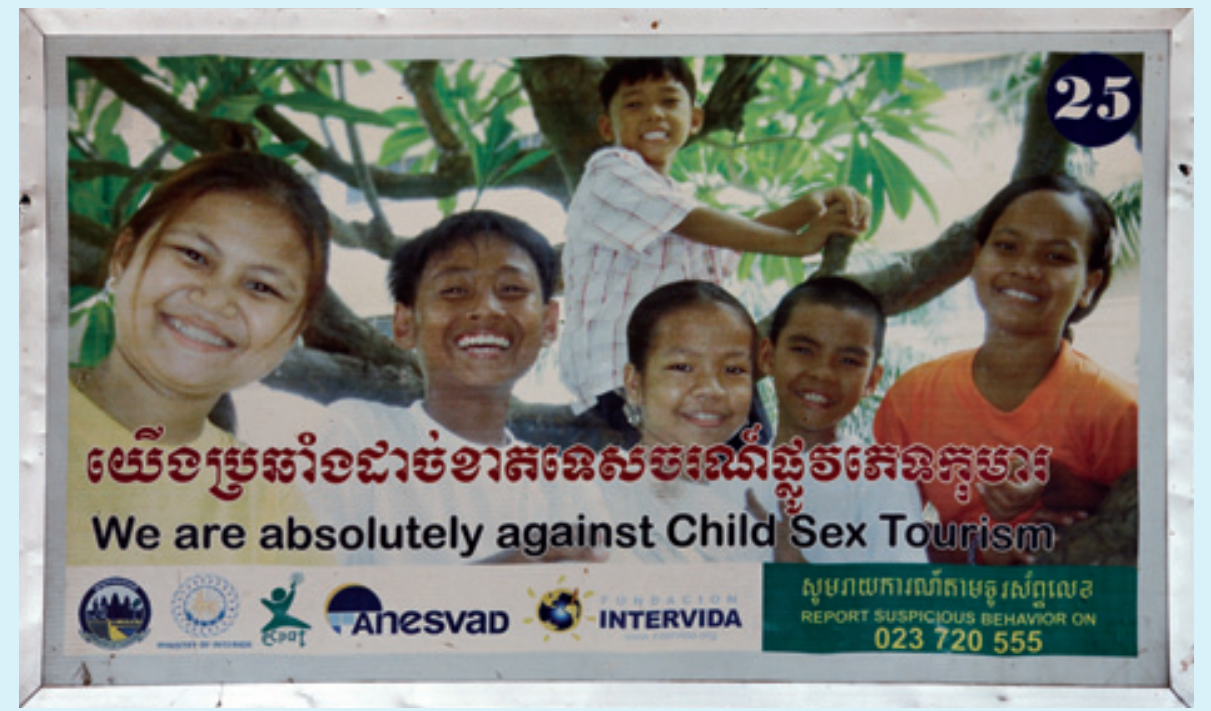

Foto (c) Sean Sprague/SpraguePhoto.com

«Jeg er ingen turistattraksjon! Det er en forbrytelse å gjøre meg til det.» Barn på plakater, i videoinnslag og brosjyrer på flyplasser i Kambodsja formidler tydelig den offentlige holdning til barneprostitusjon og er et forsøk på å bevisstgjøre turister som besøker landet.

\section{Effektiv forebygging av hivsmitte}

Behandling av mor og barn forebygger overføring av hivsmitte til barna.

Det viser en studie fra Malawi.

Uten profylakse kan nyfødte HIV-1negative barn bli smittet av en HIV-1positiv mor gjennom morsmelken. For å finne måter å forebygge slik smitte på er det gjennomført en studie i Lilongwe, Malawi, med bred utenlandsk støtte (1)

Studien omfattet knapt 2400 HIV-1positive kvinner og deres nyfødte barn. Alle fikk perinatal profylakse. Morbarn-parene ble deretter randomisert til ett av tre regimer: En gruppe barn som fortsatt var HIV-1-negative etter to uker fikk nevirapin i 28 uker, mødrene til en annen gruppe HIV-1-negative barn fikk vanlig antiviral kombinasjonsbehandling like lenge, mens barn og mødre i den tredje gruppen var kontrollgruppe. Risikoen for overføring av HIV-1-smitte var signifikant lavere i begge intervensjonsgruppene $(1,7 \%$ der barna og 2,9\% der mødrene ble behandlet, mot $5,7 \%$ i kontrollgruppen). Risikoen for HIV-1-infeksjon og død var henholdsvis $2,6 \%, 4,1 \%$ og $7 \%$.

- Et tungt amerikansk engasjement for forskning på området hiv og aids er den eneste muligheten for å få gjort en så avansert studie i Malawi, sier overlege Merethe Ravlo ved Kvinneklinikken, St. Olavs hospital, som har arbeidet en periode ved det aktuelle sykehuset i Lilongwe.

- Det er viktig å fremskaffe ny kunnskap på dette området, og artikkelen fremstår på mange måter som eksemplarisk. Men det er få malawiske kvinner som kan lese og skrive, og all kommunikasjon foregår via tolk. Derfor er det uvirkelig å lese at studien ble gjennomført etter informert samtykke. Det er også tankevekkende at land som har bidratt til den nye kunnskapen, neppe får nyte godt av den. I vestlige land og mer utviklede u-land ville morsmelkerstatning vært det selvsagte alternativet, men det gjelder dessverre ikke for denne befolkningen, sier Ravlo.

\section{Geir Jacobsen}

geir.jacobsen@yale.edu

Tidsskriftet

\section{Litteratur}

Chasela CS, Hudgens MG, Jamieson DJ et al. Maternal or infant antiretroviral drugs to reduce HIV-1 transmission. N Engl J Med 2010; 362: 2271-81. 